\title{
AGROCLIMATIC ZONING OF EUROPEAN AND ASIAN PEAR CULTIVARS WITH POTENTIAL FOR COMMERCIAL PLANTING IN SOUTHERN BRAZIL ${ }^{1}$
}

\author{
MARCOS SILVEIRA WREGE ${ }^{2}$, IVAN DAGOBERTO FAORO ${ }^{3}$, FLÁVIO GILBERTO HERTER ${ }^{4}$, \\ CRISTINA PANDOLFO ${ }^{3}$, IVAN RODRIGUES DE ALMEIDA ${ }^{5}$, JOSÉ MARIA FILIPPINI ALBA ${ }^{6}$, \\ JOSÉ FRANCISCO MARTINS PEREIRA ${ }^{7}$
}

\begin{abstract}
Pear is among the fruits of major commercial interest in the world and one of the most imported in Brazil. Brazilian production is very small and the fruit quality is low, due to production problems. The success of culture in the country, among other factors, may be linked to the choice of cultivars, pollinating and rootstocks better adapted to local conditions, and thus depend on the particulars of an agricultural zoning. The aim of this study was to identify, in southern Brazil, homogeneous climatic zones with potential for growing of European and Asian pears, through climate risk studies. The regions were defined by the seasonal availability of chilling hours $\left(<7.2^{\circ} \mathrm{C}\right)$ accumulated during the period from May to September and the monthly risk of drought. The analysis allowed the recognition of four homogeneous areas for the production of pears in southern Brazil.

Index terms: agricultural zoning; Pyrus communis L.; Pyrus pyrifolia L.; reduction of climatic risks; adapted cultivars; climatic conditions.

\section{ZONEAMENTO AGROCLIMÁTICO DE PEREIRAS EUROPÉIAS E ASIÁTICAS COM POTENCIAL PARA PLANTIO COMERCIAL NA REGIÃO SUL DO BRASIL}

RESUMO - A pera está entre as frutas de maior interesse comercial no mundo e é a fruta mais importada pelo Brasil. A produção brasileira é muito pequena, e a qualidade da fruta não tem padrão comercial adequado, em função da falta de adaptação das peras de qualidade às condições edafoclimáticas brasileiras. O sucesso da cultura no País, entre outros fatores, pode estar associado à escolha das cultivares comerciais, polinizadoras e porta-enxertos mais bem adaptados às condições edafoclimáticas locais, dependendo, portanto, das indicações de um zoneamento agrícola. Assim, o objetivo deste estudo foi identificar, na região Sul do Brasil, zonas climáticas homogêneas com potencial para plantios comerciais de pereiras europeias e asiáticas, por meio de estudos de riscos climáticos. As regiões foram delimitadas pela disponibilidade estacional de horas de frio $(<7,2 \mathrm{oC})$ acumuladas no período entre maio e setembro, e pelo risco mensal de ocorrência de déficit hídrico. A análise permitiu o reconhecimento de quatro zonas homogêneas para produção comercial de peras na região Sul.

Termos para indexação: zoneamento agrícola, Pyrus communis L., Pyrus pyrifolia L., redução dos riscos climáticos, adaptação de cultivares, condições climáticas.

\footnotetext{
1(Paper 223-15). Received September 29, 2015. Accepted February 24, 2016.

${ }^{2}$ Agronomist, PhD, Researcher at Embrapa Forests. Email: marcos.wrege@embrapa.br

${ }^{3}$ Agronomist, PhD, Researcher at Epagri. Email: faoro@epagri.sc.gov.br; pandolfo@epagri.sc.gov.br

${ }^{4}$ Agronomist, PhD, Professor of UFPel. Email: flavioherter@gmail.com

${ }^{5}$ Geographer, PhD, Researcher at Embrapa Temperate Climate. Email: ivan.almeida@embrapa.br

${ }^{6}$ Agronomist, PhD, Researcher at Embrapa Clima Temperado. Email: jose.filippini@embrapa.br

${ }^{7}$ Agronomist, PhD, Researcher at Embrapa Clima Temperado. Email: jose.pereira@embrapa.br
} 


\section{INTRODUCTION}

European (Pyrus communis L.) and Asian pear cultivars ( $P$. pyrifolia L.) belong to a genus of criolphic species (cryo: cold, phylum: friend) of temperate climate, originating in Europe and Asia, respectively (Faoro, 2001). Asian species can adapt to less cold climates.

Most crops are grown in temperate regions, around the $40^{\circ}$ North and South parallels, in very cold areas, including Sweden, Switzerland, Russia, as well as Mediterranean countries such as Portugal, Spain, Italy and France.

Pear is among the fruits of major commercial interest in the world and is the most imported by Brazil. Consumption currently stands at around 160,000 tons, for an annual national production of 16,000 tons (FAO, 2012, IBGE, 2013), which is far below demand and demonstrating a very large import dependency, mainly from Mercosur countries, mainly Argentina and Chile.

Brazilian productivity and fruit quality are low, and in many cases, fruit does not have the adequate standard to meet the consumer market. These problems are due to fruiting problems, which occurs due to the low rate of flower bud formation and low rate of fruit fixation, which negatively interfere with the productivity of orchards and, consequently, make the activity unattractive (Pereira, 2010; Herter, 2010; Wrege et al., 2006). In addition, the low amount of cold units during winter induces the formation of lower quality fruits. Thus, the limitations for the development of this culture in Brazil are in the cultivation and not in the market.

The problems related to the crop may be related to the over-vigor of plants. Pears with higher vigor are less productive, according to Prezotto (2008) and Pertineli et al. (2012). In the first attempts of introduction of the crop in Brazil, high-vigor rootstocks (Pyrus spp) were used, leading to low productivity and fruit quality. The lack of rootstocks suitable for different edaphoclimatic conditions is among the obstacles to the crop expansion (Fachinello et al., 2011).

Less vigorous rootstocks are being researched, such as quince tree (Cydonia oblonga Mill.), which has been used in the major pear producing regions in the world, inducing precocity, and pear productivity quality.

However, the ideal rootstock for the Brazilian conditions has not yet been defined due to compatibility problems between canopy and rootstock.

The southern region of Brazil is one of the most important agricultural regions in the country for the growing of temperate climate fruits, such as apple, grape, peach, nectarine, among others. Pear, however, is still not very expressive, with a very small planted area, a little more than 950 hectares, according to updated data from Deral in Paraná, Epagri in Santa Catarina (Faoro, 2014) and the Department of Agriculture of Rio Grande do Sul (Unpublished data).

The most important risk factors for pear cultivation in southern Brazil are frost and water deficit, which account for the majority of agricultural losses (Göpfert et al., 1993). In addition, for most temperate climate fruit species, it is still necessary that a certain number of chilling hours in fall-winter occur to stop the dormancy of plants and reach high productive potential (Sousa et al. 2009).

Chilling hours are the sum of the number of hours in which the air temperature remains below a certain value, generally $7.2^{\circ} \mathrm{C}$ during fall and winter, which is the period of pear dormancy. In this period, plants do not completely paralyze physiological activities. Exposure to low temperatures stimulates biochemical activities and concentration of hormones, mobilizing carbohydrates that favor the budding of vegetative and floriferous buds (Almeida and Antunes, 2012). Therefore, the dormancy period is necessary to standardize sprout and flowering, which occur immediately after the winter resting period, usually in late winter and early spring.

Cryophatic species that do not have the amount of cold they naturally need are at risk of phenological anomalies, with decreased productivity and longevity (Sousa et al., 2009). In the case of tree, 'delayed foliation' occurs. The plant sprouts and flowers irregularly, which can reduce productivity and fruit quality (Faoro, 2001).

The mountainous regions in southern Brazil are, in general, able to meet the needs of fruit species such as pear. However, due to the irregularity of the winter conditions in these regions, the ideal is the use of adapted cultivars that can have high productivity and plant longevity meeting their minimum requirements (Almeida and Antunes, 2012; Massignam et al., 2006 ).

The cold needs for pear, in general, are high. Some cultivars need about 1400-2000 chilling hours accumulated under temperatures below $7.2^{\circ} \mathrm{C}$. The cultivars currently used in Brazil require 400 to 1000 chilling hours accumulated in the fall-winter period (May-September), and European cultivars generally needing longer chilling hours than Asian cultivars (Faoro, 2001).

Frosts do not pose a risk for pear production, 
except for late spring frosts, more common to occur in lowlands or in the vicinity of closed forests, where cold air accumulation usually occurs, or when cultivars with low cold needs are planted in regions with late frost. The risk of frosts can be greatly reduced if these sites are avoided or if cultivars that are most suitable for each environment are selected.

Pear tree fruiting depends on cross pollination, coming from another cultivar in the same orchard so that flower fertilization occur, because the species is self-incompatible. Therefore, it is necessary to associate other pollinator cultivars with flowering at coincident times (Faoro, 2001), so that greater production occurs and the fruits have better quality (Wrege et al., 2006).

The states of Paraná, Santa Catarina and Rio Grande do Sul are those that can offer the best climatic conditions for the development of the pear tree. However, small planting areas are also observed in São Paulo and Minas Gerais (Fioravanco, 2007). In these states, pear tree can also be cultivated in high altitude zones, selecting for this cultivars that have the lowest chilling needs.

The crop success, among other factors, may be associated to the choice of commercial cultivars, pollinators and rootstocks better adapted to local soil and climatic conditions, depending, therefore, on agricultural zoning indications. Thus, the aim of this work was to elaborate the agroclimatic zoning of pear crop for the southern region of Brazil.

\section{MATERIAL AND METHODS}

In this work, several databases were used, belonging to several research institutions. The first was composed using data from state research institutions in the southern region of Brazil, among them: the Agronomic Institute of Paraná (IAPAR), the State Enterprise of Agricultural Research and Rural Extension of Santa Catarina (Epagri) and State Agricultural Research Foundation of Rio Grande do Sul (Fepagro). The second was composed using data from federal institutions, including National Water Agency (ANA), the $8^{\text {th }}$ District of Meteorology of the National Meteorological Institute $\left(8^{\text {th }}\right.$ Disme / Inmet), Federal Universities (Federal University of Pelotas - UFPel and Federal University of Paraná UFPR) and Embrapa (Embrapa Clima Temperado and Embrapa Trigo), and also stations of the National Institute of Agricultural Research (INIA) of Uruguay on the Brazil / Uruguay border (Wrege et al., 2011).

The first base was used mainly to calculate temperature and related indexes (e.g., chilling hours), in addition to rainfall data. The second base was used only to calculate rainfall. All data were first evaluated for absence of errors, completeness and consistency in the work developed by Wrege et al. (2011).

\section{Chilling hour calculation}

Data from weather stations in the southern region of Brazil were used, with a total of 93 stations with information of cold $\left(<7.2^{\circ} \mathrm{C}\right)$ during the fallwinter period (from May to September). The period considered in the analysis was from 1976 to 2005, with complete climatic series following WMO (1984) standards, which recommends at least 30 years of records for the calculation of climatological values.

Data from 93 stations with chilling hour values were georeferenced with latitude and longitude (represented in decimal degrees and negative values) and altitude (values represented in meters above sea level) to generate a simple linear regression equation, allowing calculating the chilling hours according to latitude, longitude and altitude of any georeferenced point in the southern region of the country and, thus, to be able to draw a chilling hours map to be used in the indication of cultivars for the agroclimatic zoning. The sum of the chilling hours for each weather station was obtained by reading, each year, the time in which the air temperature remained below $7.2^{\circ} \mathrm{C}$. This reading was made for Fepagro (Rio Grande do Sul), CIRAM / Epagri (Santa Catarina) and IAPAR (Paraná) stations. The period analyzed was from 1976 to 2005 (Wrege et al., 2011). Chilling hour data were correlated with altitude, latitude and longitude of each station, elaborating a multiple linear regression equation, described as follows:

Chilling hours $=-1866.52-52.71 \times$ latitude $9.81 \times$ longitude $+0.3248 \times$ altitude

\section{Water balance calculation}

In the water balance calculation, data from two NETWORK weather sations in the southern region of Brazil were used, one with 564 rainfall stations and the other with 123 rainfall stations with temperature, chilling hours and rainfall data. Potential evapotranspiration values were calculated, using temperature by the Thornthwaite method (1948), for the 123 stations.

The period considered was from 1976 to 2005 , with complete climatic series as much as possible following WMO (1984) standards, which recommends at least 30 years of records for the calculation of climatological values.

Subsequently, data were georeferenced with latitude and longitude (in decimal degrees and negative values) and altitude (in meters above sea level). 
In the first step, the potential evapotranspiration values (equations 1 to 4 ) were calculated, as follows:

$$
\mathrm{ETP}=\mathrm{f} \times 16 \times(10 \times \mathrm{tmed} / \mathrm{I})^{\mathrm{a}}
$$

(Equation 1)

and,

$$
\begin{aligned}
& \mathrm{f}=[0.006 \times(-1) \times \text { latitude }+1.01] \quad(\text { Equation 2) } \\
& \mathrm{I}=\quad \mathrm{I}=\sum_{12}^{1}(\text { tmed } / 5)^{1,514} \quad(\text { Equation 3) }
\end{aligned}
$$$$
\mathrm{a}=6.75 \times 10^{-7} \times \mathrm{I}^{3}-7.71 \times 10^{-5} \mathrm{xI}^{2}+0.01791 \times \mathrm{I}+0.492
$$

where:

$\mathrm{f}$ : represents the adjustment function of the model for each location, considering that the equation is given to calculate ETP in a period of 12 hours of solar brightness, which does not occur in all regions;

$\mathrm{I}$ : is the annual heat index;

a: is the cubic function of the annual heat index;

tmed: is the average air temperature in the months from January to December, in ${ }^{\circ} \mathrm{C}$;

$\sum_{12}^{1}$ tmed: is the sum of the average air temperatures from January to December, in ${ }^{\circ} \mathrm{C}$.

The latitude, in the equation, was expressed in negative decimal degrees and served to calibrate the ETP values for each location.

In the next step, data from the 123 stations for which potential evapotranspiration (ETP) values calculated were used to generate simple linear regression equations, allowing potential evapotranspiration to be calculated as a function of latitude, longitude, and altitude for any georeferenced point in the southern region of Brazil (Table 1). Thus, it was possible to estimate it for all 564 georeferenced points in rainfall stations and calculate the monthly P-ETP values, as follows (equation 5):

Water availability $=\mathrm{P}-\mathrm{ETP}$

(Equation 5)

where:

P: total rainfall occurred in the months ( $\mathrm{mm})$ for the 564 rainfall seasons and 123 stations with rainfall and potential evapotranspiration data;

ETP: total potential evapotranspiration occurred in months $(\mathrm{mm})$, calculated for each of the 123 stations with rainfall and temperature data by equations 1 to 4 or for each of the 564 rainfall stations by equation 6 .
$\mathrm{ETP}=$ constant $+\alpha \times$ latitude $+\beta \times$ longitude $+\chi \mathrm{x}$ altitude

(Equation 6)

Table 1 Coefficients of simple linear regression equations used to calculate monthly potential evapotranspiration (ETP) as a function of latitude, longitude and altitude for the southern region of Brazil (Wrege et al., 2011).

Thus, it was possible to map climatic data in geographic information systems (GIS). The relief map (GTOPO30) was obtained from the United States Geological Survey (USGS, 1999), corrected by UFRGS by Weber et al. (2004), with altitude values spatially represented every 30 meters.

\section{RESULTS AND DISCUSSION}

Due to its geographical position between middle latitudes, together with the relief conditions and the behavior of cold fronts, the southern region of Brazil has more than one climatic type, with predominance of temperate climate in the mountains and subtropical climate in regions of lower altitude (Marengo et al., 2012). Pear is a species of temperate climate, and should be indicated for planting, therefore, in the mountainous zones of altitude, where there is enough cold for its development, with total chilling hours varying according to the altitude, mainly in the mountainous regions of Santa Catarina and Rio Grande do Sul (Figure 1) (Massignam et al., 2006). In colder areas, productivity tends to be higher (Faoro, 2001).

The agroclimatic zoning of the pear tree for the southern region of Brazil is presented in Figure 2 and Table 2. The mountainous regions have favorable zones for planting, while lower altitude regions, represented by valleys of the main rivers in the region, are not recommended, because they do not have the amount of cold necessary for the development of the species. Cold is necessary to stimulate the sprouting of the vegetative and floriferous buds and, thus, to obtain fruits of quality and size, with high productivity. Due to the irregularity of the winter conditions in southern Brazil, the use of better adapted cultivars, with productivity and longevity even providing minimum requirements is recommended (Almeida and Antunes, 2012).

In all zones identified as favorable for pear production, it is possible to find strategic areas for orchards implantation, with low risk of late spring frosts. Particularly in regions of higher altitude, in order to reduce the risk of late frost occurrence, it is necessary to search for areas far from the lowlands 
and to choose for planting, preferably, the north exposure face of the terrain, protecting the orchard from cold fronts and increasing the exposure time to solar radiation. Lowlands, depressions and the proximity of closed forests favor the damming of cold air and, consequently, the occurrence of frost (Wrege et al., 2006) and should be avoided.

All species of the genus Pyrus spp. are selfincompatible and thus need cross-pollination to produce fruits. However, there are rare exceptions, such as the Osanijisseiki cultivar, which is self- compatible (Faoro, 2001). However, in general, the best fruit yields are obtained with the intercalation of commercial cultivars and pollinator cultivars (Centelhas Quezada et al., 2003). In the selection of the site to establish the orchard, therefore, at least two pollinator cultivars must be implanted, following the combinations shown in Table 3 (Centelhas Quezada, 2003; Wrege et al., 2006).

The coastal zone of the southern region of the country is not recommended for pear cultivation due to the high relative air humidity, which favors the appearance of several diseases.

TABLE 1 - Coefficients of simple linear regression equations used to calculate monthly potential evapotranspiration (ETP) as a function of latitude, longitude and altitude for the southern region of Brazil (Wrege et al., 2011).

\begin{tabular}{|l|c|c|c|c|}
\hline Station & constant & $\alpha$ & $\beta$ & $\chi$ \\
\hline January & 22.46 & 2.03 & -3.34 & -0.035 \\
\hline February & 93.44 & 1.82 & -1.44 & -0.030 \\
\hline March & 113.89 & 2.72 & -1.41 & -0.028 \\
\hline April & 137.30 & 3.13 & -0.52 & -0.019 \\
\hline May & 129.31 & 1.50 & 0.69 & -0.012 \\
\hline June & 110.02 & 1.69 & 0.51 & -0.006 \\
\hline July & 103.84 & 1.96 & 0.23 & -0.006 \\
\hline August & 99.16 & 2.76 & -0.49 & -0.006 \\
\hline September & 106.09 & 4.12 & -1.29 & -0.011 \\
\hline October & 84.59 & 3.75 & -1.73 & -0.014 \\
\hline November & 70.35 & 3.65 & -2.56 & -0.022 \\
\hline December & 13.59 & 2.76 & -3.72 & -0.029 \\
\hline
\end{tabular}


TABLE 2 - European and Asian pear cultivars recommended for commercial planting in the southern region of Brazil, according to the homogeneous climatic zones.

\begin{tabular}{|c|c|c|c|c|}
\hline \multirow{2}{*}{ Cultivar } & \multicolumn{4}{|c|}{ Zones } \\
\hline & 1 & 2 & 3 & 4 \\
\hline Abate Fetel & & & & $x$ \\
\hline Carrick & $\mathrm{X}$ & $\mathrm{X}$ & $\mathrm{X}$ & $x$ \\
\hline Cascatense & $\mathrm{x}$ & $\mathrm{x}$ & $\mathrm{X}$ & \\
\hline Clap'sFavorite & & & $\mathrm{x}$ & \\
\hline Centenária & $\mathrm{x}$ & $\mathrm{x}$ & & \\
\hline Forelle $^{1}$ & $\mathrm{X}$ & $\mathrm{X}$ & $\mathrm{X}$ & \\
\hline Garber & $\mathrm{x}$ & $\mathrm{x}$ & & \\
\hline Housui & & $\mathrm{x}$ & $\mathrm{x}$ & $\mathrm{x}$ \\
\hline Kieffer & $\mathrm{x}$ & $\mathrm{x}$ & & \\
\hline Kousui & & $\mathrm{x}$ & $\mathrm{x}$ & $\mathrm{x}$ \\
\hline Le Conte & $\mathrm{x}$ & $\mathrm{x}$ & & \\
\hline Max RedBartlett & & & & $x$ \\
\hline Nijisseiki $^{1}$ & & & $\mathrm{X}$ & $\mathrm{x}$ \\
\hline Nitaka & & $\mathrm{x}$ & $\mathrm{x}$ & $x$ \\
\hline Packam's Triumph $^{1}$ & $\mathrm{X}$ & $\mathrm{X}$ & $\mathrm{X}$ & $\mathrm{x}$ \\
\hline Primorosa & $\mathrm{x}$ & $\mathrm{x}$ & & \\
\hline Rocha $^{2}$ & & & $\mathrm{x}$ & $\mathrm{x}$ \\
\hline Santa Maria & & & $\mathrm{x}$ & $\mathrm{x}$ \\
\hline Seleta & $\mathrm{x}$ & $\mathrm{x}$ & & \\
\hline Shinseiki & $\mathrm{x}$ & $\mathrm{x}$ & $\mathrm{x}$ & \\
\hline Shinsui & $\mathrm{X}$ & $\mathrm{X}$ & & \\
\hline Smith & $\mathrm{x}$ & $\mathrm{x}$ & & \\
\hline Teen & $\mathrm{x}$ & $\mathrm{x}$ & & \\
\hline Tenra & $\mathrm{x}$ & $\mathrm{x}$ & & \\
\hline Triunfo & $\mathrm{x}$ & $\mathrm{x}$ & & \\
\hline Yali & $\mathrm{x}$ & $\mathrm{x}$ & $\mathrm{x}$ & $\mathrm{x}$ \\
\hline
\end{tabular}

${ }^{1}$ Chemical treatment to aid in the process of overcoming dormancy

${ }^{2}$ Avoid planting in lowlands due to problems of late spring frosts. 
TABLE 3- Combination between commercial and pollinator pear cultivars.

\begin{tabular}{ll}
\hline Commercial pear cultivar & Pollinator pear cultivar \\
\hline Abate Fetel & Forelle, Packham's Trimph, Winter, Nelis, Housui, \\
Carrick & Kousui \\
Cascatense & Kieffer, Yali \\
Clapp'sFavorite & Flordahome or IAC 9040 \\
Forelle & Abate Fetel, Forelle \\
Garber & Abate Fetel \\
Housui & Carrick, Kieffer \\
Kieffer & Packham'sTriumph, or Shinseiki, Kousui, Kikusui, \\
Kousui & Nijisseiki, Yali \\
Le Conte & Carrick, Garber, Tenn \\
Max Red Bartlett (or Red Bartlett) & Packham'sTriumph, Shinseiki \\
Packham'sTriumph & Triunfo \\
Nijisseiki (or Século XX) & Packham's Triumph, Highland, Kousui, Nijisseiki \\
Niitaka & Max Red Bartlett, Winter Nelis, Housui, Kousui \\
Rocha & William's (or Bartlett), Shinseiki, Kousui \\
Santa Maria & Housui \\
Seleta & Housui \\
Shinseiki & Packham'sTriumph \\
Shinsui & - \\
Smith & Shinsui, Housui \\
Suissei & Nijisseiki, Shinseiki \\
Tenn & Kieffer, Yali \\
Tenra & Nijisseiki, Shinseiki \\
Triunfo & Kieffer \\
Yali & - \\
William's ${ }^{1}$ & Kieffer, Le Conte \\
\hline Varick, Kieffer \\
\hline
\end{tabular}

${ }^{1}$ Variations in the coincidence of flowering periods between commercial and pollinator cultivars may occur between years, depending on planting areas and climatic conditions. An example occurs in the zones of higher altitude between William's and Packham'sTriumph cultivars. Therefore, the use of two or more pollinator cultivars that best adapt and the placement of large numbers of strong hives in the orchard, in order to facilitate cross-pollination between plants are indicated. 


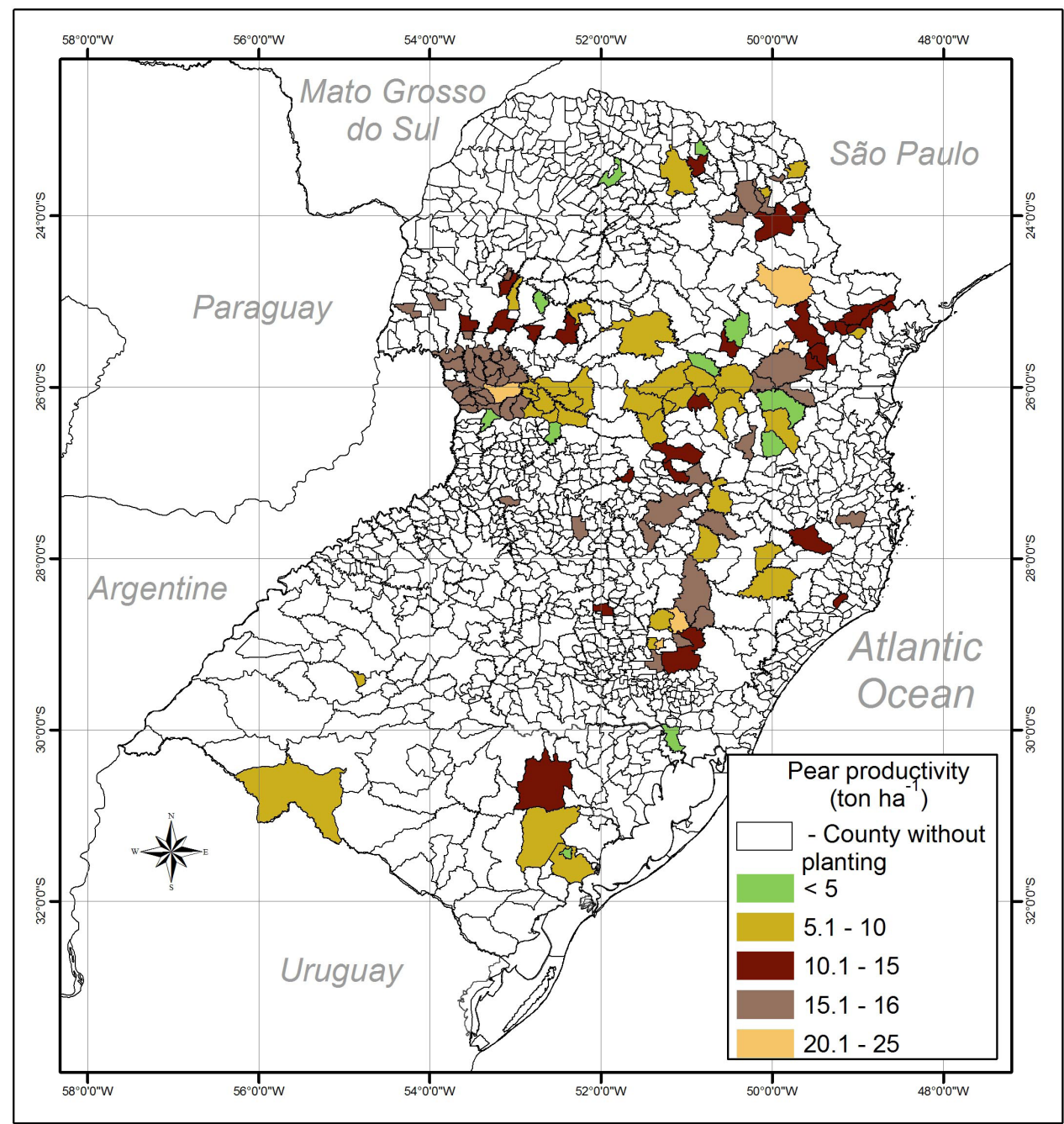

FIGURE 1- Pear productivity in municipalities with fruit production in southern Brazil (Source: adapted from Deral, Faoro et al., 2014, Department of Agriculture of Rio Grande do Sul, unpublished official data). 


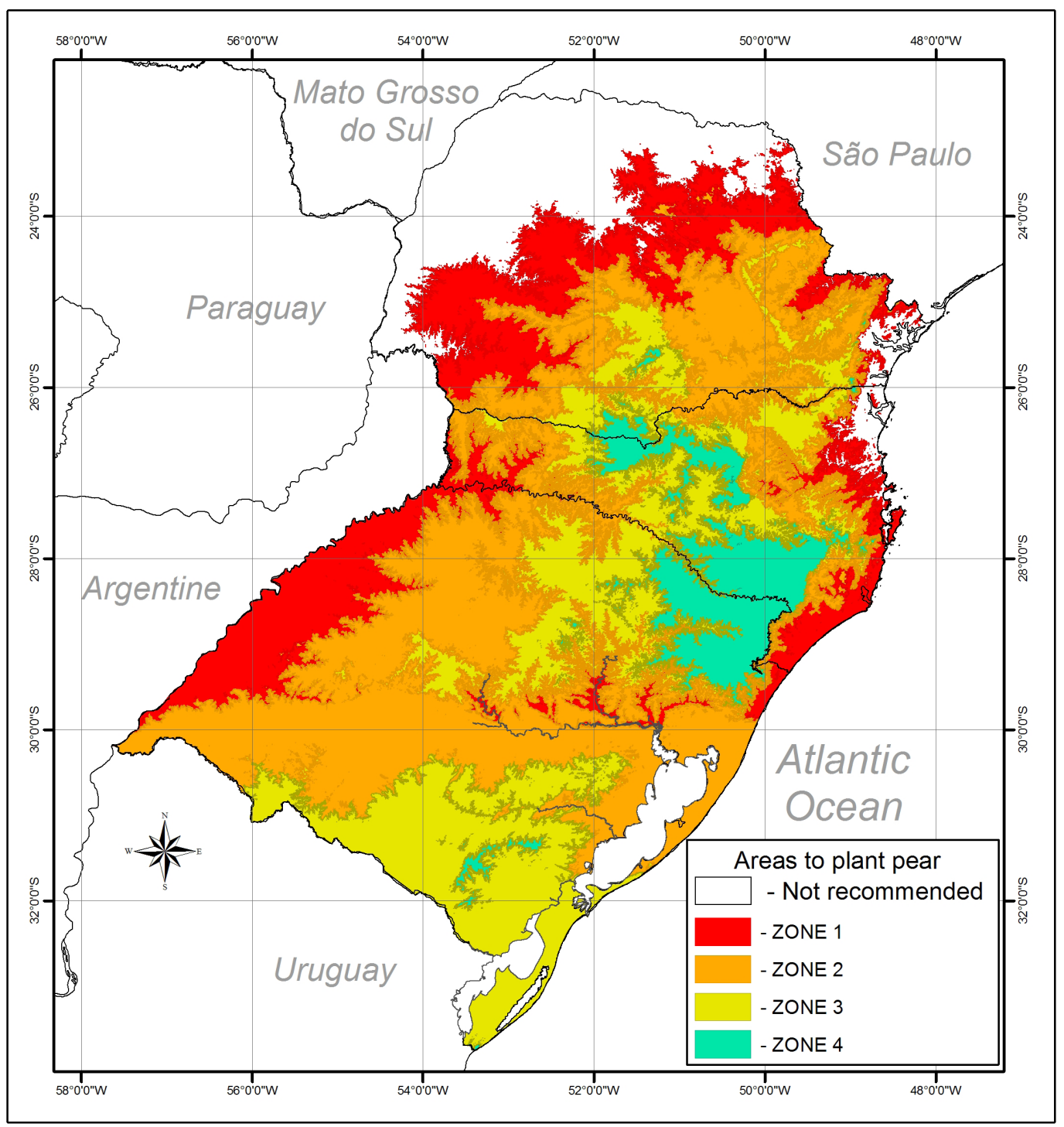

FIGURE 2-Areas with lower climatic risks and indication of European and Asian pear cultivars for commercial planting in southern Brazil 


\section{CONCLUSIONS}

In Brazil, the sum of chilling hours, even in the southern region, is low, and therefore the planting of pear cultivars with low cold needs should be indicated.

For European and Asian pear cultivars, the southern mountainous regions of the country have the best conditions for pear cultivation, because they are the coldest areas and therefore have the necessary cold in the fall-winter period that favors fruit development;

The analyses carried out in this work allowed the recognition of four homogeneous zones for commercial pear production in southern Brazil.

\section{REFERENCES}

ALMEIDA, I.R. de; ANTUNES, L.E.C. Necessidades climáticas e influência do clima sobre adaptação, produção e qualidade. In: ANTUNES, L.E.C.; HOFFMANN. Pequenas frutas: 500 perguntas, 500 respostas. Você pergunta, a Embrapa responde. Brasília, DF: Embrapa, 2012. p.41-49.

CENTELHAS QUEZADA, A.; NAKASU, B.H.; HERTER, F.G. (Ed.). Pêra: produção. Pelotas: Embrapa Clima Temperado, 2003. (Frutas do Brasil, 46).

FACHINELLO, J.C.; PASA, M.; SCHMITIZ, J.D.; BETEMPS, D.L. Situação e perspectivas da fruticultura de clima temperado. Revista Brasileira de Fruticultura, Jaboticabal, v.33, n.1, p.109-120, 2011. Volume especial

FAO. Faostat database prodstat. Disponível em: $<$ http://faostat3.fao.org/home/E $>$. Acesso em: 15 jan. 2012.

FAORO, I.D. Nashi: a pêra japonesa. Florianópolis: Epagri, 2001. p.15-65.
FAORO, I.D.; SOUZA, Z. da S.; DENARDI, F.; KVITSCHAL, M.V. Pera. In: EPAGRI. Avaliação de cultivares para o estado de Santa Catarina 2014-2015. Florianópolis: Epagri, 2014. p.54-57.

FIORAVANCO, J.C.A. A cultura da pereira no Brasil: situação econômica e entraves para o seu crescimento. Informações Econômicas, São Paulo, v.37, n.39, 2007.

GÖPFERT, H.; ROSSETTI, L.A.; SOUZA, J. Eventos generalizados e seguridade agrícola. Brasília: IPEA, 1993. 65 p.

HERTER, F.G.; PEREIRA, J.F.M. Tecnologias para o aumento da produtividade e regularidade de produção de pêra na região sul do Brasil. In: REUNIÃO TÉCNICA DA CULTURA DA PEREIRA, 2. 2008 , Lages. Anais ... Lages: UDESC, 2008. p. 33-37. (3)

IBGE - Instituto Brasileiro de Geografia e Estatística. Sistema de recuperação automática - SIDRA. Disponível em: < http://www.sidra.ibge.gov.br/>. Acesso em: 10 maio 2013.

MARENGO, J.A.; LIEBMANN, B.; GRIMM, A.M.; MISRA, V.; SILVA DIAS, P.L.; CAVALCANTI, I.F.; CARVALHO, L.M.V.; BERBERY, E.H.; AMBRIZZI, T.; VERA, C.S.; SAULO, A.C.; NOGUÉS-PAEGLE, J.; ZIPSER, E.; SETH, A.; ALVES, L.M. Recent developments on the South American monsoon system. International Journal of Climatology, New York, v.32, p.1-21, 2012.

MASSIGNAM, A.M.; PANDOLFO, C.; HAMMES, L.A.; PEREIRA, E.S. Probabilidade de ocorrência do total anual de horas de frio $\left(\mathrm{HF} \leq 7,2^{\circ} \mathrm{C}\right)$ em Santa Catarina. Revista Brasileira de Agrometeorologia, Santa Maria, v.14, n.3, p.301-308, 2006.

MARAFON, A. C.; HERTER, F. G.; HAWERROTH, F. J.; SILVA, A. S. da . Floral bud initiation and development of three pear tree (Pyrus sp.) cultivars in two subtropical regions during the summer period. Acta Horticulturae, v. 872, p. 121-126, 2010.

PEREIRA, J.F.M.; HERTER, F.G. Tecnologias para o aumento da produtividade e regularidade de produção de pera na região sul do Brasil. In: REUNIÃO TÉCNICA DA CULTURA DA PEREIRA: BUSCA PELA IDENTIDADE NACIONAL, 3., 2010, Lages. Anais ... Lages: UDESC, 2010. p. 39-45. 
PERTINELLI, R.; MACHADO, B.D.; MAGRO, M.; VENDRUSCULO, F.T.; RUFFATO, L.; KRETZSCHMAR, A.A. Crescimento vegetativo e produtividade de genótipos de pereira europeia sobre o porta enxertoAddam's no Planalto Catarinense. In: CONGRESSO BRASILEIRO DE FRUTICULTURA, 22., 2012, Bento Gonçalves. Anais... Campinas: SBF, 2012. p.3161-3164.

PREZOTTO, M.E. Vigor e compatibilidade de enxertia de pereiras cv. William's sobre diferentes porta enxertos. In: CONGRESSO DE INICIAÇÃO CIENTÍFICA, 17., 2008. Pelotas. Anais... p. 29-34.

SOUSA, F.A.; SOUZA, M.J.H. de; RIBEIRO, A.; LEITE, F.P. Disponibilidade do número de horas de frio em Cocais, Minas Gerais. In: CONGRESSO BRASILEIRO DE AGROMETEOROLOGIA, 16., 2009, Belo Horizonte. Anais... Disponível em: $<$ http://www.sbagro.org.br/anais_congresso_2009/ cba2009/>. Acesso em: 22 dez. 2014.

THORNTHWAITE, C.W. An approach toward a rational classification climate. Geographical Review, New York, v.38, p.55-94, 1948.
USGS - United States Geological Survey. Global 30 arc second elevation data GTOPO30. Sioux Falls, 1999. Disponível em: $\leq$ http://edcwww.cr.usgs.gov/ landdaac/GTOPO30>. Acesso em: 10 jul. 1999.

WEBER, E.; HASENACK, H.; FERREIRA, C.J. Adaptação do modelo digital de elevação do SRTM para o sistema de referência oficial brasileiro e recorte por unidade da federação. Porto Alegre: UFRGS, Centro de Ecologia, 2004. Disponível em: <http://www.ecologia.ufrgs.br/ labgeo $>$. Acesso em: 17 jul. 2008.

WMO - World Meteorological Organization. Glossary of terms used in agrometeorology. Geneva : World Meteorological Organization, 1984. 254 p. (Report, 20)

WREGE, M. S.; HERTER, F.G.; CAMELATTO, D.; STEINMETZ, S.; REISSER JR, C.; GARRASTAZU, M.C.; FLORES, C.A.; IUCHI, T.; BERNARDI, J.; VERÍSSIMO, V.; MATZENAUER, R. Zoneamento agroclimático para pereira no Rio Grande do Sul. Pelotas: Embrapa Clima Temperado, 2006. 29 p. (Documentos, 182).

WREGE, M.S.; STEINMETZ, S.; REISSER JR, C.; ALMEIDA, I.R. Atlas climático da região Sul do Brasil: estados do Paraná, Santa Catarina e Rio Grande do Sul. Pelotas: Embrapa Clima Temperado; Colombo: Embrapa Florestas, 2011. 336 p. 